\title{
Bacillus and Serratia Species for Scarab Control
}

\author{
Michael G Klein, Harry K Kaya*
}

\begin{abstract}
USDA, Agricultural Research Service, Application Technology Research Unit, Horticultural Insects Research Laboratory, Ohio Agricultural Research and Development Center, Wooster, OH 44691 USA *Department of Nematology, University of Califomia, Davis, CA 95616 USA
\end{abstract}

Few microorganisms are commercially available for use against white grubs (larvae of Scarabaeidae). Entomopathogenic bacteria, particularly Bacillus popilliae, have been used the longest for white grub suppression. Other bacteria, namely B. thuringiensis and Serratia spp. offer promise for future control. This paper examines two genera of bacteria (Bacillus and Serratia) from the historical and current perspective. Bacillus popilliae, the first microbial control agent registered in the United States, has a long history of use in suppressing populations of the Japanese beetle, Popillia japonica. However, lack of in vitro production and the slow and sporadic nature of its activity, severely limits its utilization. B. thuringiensis, the most widely used microbial pesticide, has not been used for scarab, control. However, strains with scarab activity have recently been discovered. Scarab larvae have been collected in the United States with signs and symptoms similar to those characteristic of amber disease (caused by Serratia entomophila) in the New Zealand grass grub, Costelytra zealandica. A total of 147 bacteria have been obtained from the digestive tracts of larvae of the Japanese beetle and masked chafers, Cyclocephala spp., as well as from larvae and soil collected in Japan and China. Seventy five of these have been identified as Serratia spp. Most (40) of the remaining bacteria are in the genus Enterobacter. A majority of the bacteria (73) and of the Serratia (38) came from $\mathrm{P}$. japonica.

Key words: entomopathogenic bacteria - Bacillus - Serratia - scarabs - milky disease - amber disease

Scarab beetles and their larvae are serious pests of crops, ormamentals and turf throughout the world (Jackson 1992). They are likely to increase in significance because of the decreasing availability of conventional chemical insecticides. Unfortunately, there are very few microorganisms commercially available for use against these pests that can effectively and economically replace the broad spectrum chemical insecticides.

A recent book (Jackson \& Glare 1992) surveyed the status of pathogens against scarabs, and several reviews (Klein 1988, 1989, 1995, Cranshaw \& Klein 1994, Klein \& Jackson 1992) examined the status of microorganisms against turf and omamental pests in general. These authors found that few microorganisms are now in use or undergoing testing in the United States. Only one bacterium, Bacillus thuringiensis (Bt),

\footnotetext{
This article reports results of research only. Mention of a proprietary product does not constitute an endorsement or a recommendation for its use by USDA.

This work was partially supported by The United States Golf Association, Green Section Research, and the UC IPM Project.

Received 30 August 1994
}

Accepted 13 December 1994 has had substantial commercial production, but still makes up less than $1 \%$ of the total pesticide market.

Many bacteria have been associated with natural mortality in scarab populations. These infections can be seen as conspicuous epizootics in insect populations (Kaya et al. 1993) or can weaken insects causing them to be more susceptible to other factors that lead to their death (Thurston et al. 1994). Using these bacteria as biological control agents offers great potential. They can be employed as classical biological control agents by introducing them into new environments, but are more commonly used for augmentation programs. This augmentation can be done on an inundative basis which utilizes the bacteria like conventional insecticides (e.g., $\mathrm{Bt}$ and the amber disease bacteria, Serratia spp.). For this approach, bacteria do not need to reproduce or spread to be successful. Another augmentative approach is done on an inoculative basis that relies on the build up and spread of the microorganism in the field and is characteristic of the milky disease bacterium, B. popilliae.

This paper will focus on three bacteria, two Bacillus species and the genus Serratia, and examine their past history and potential role in suppressing scarab populations. 


\section{MILKY DISEASE BACTERIA}

The history and use of the milky disease bacterium, $B$. popilliae, has been extensively reviewed in several recent articles (Klein 1988, 1992, 1995, Stahly et al. 1992, Klein \& Jackson 1992, Cranshaw \& Klein 1994) and will not be covered in detail here. It was the first microbial agent registered in the United States in 1948, but had been used for suppressing Japanese beetle populations since the early 1940s. Currently, it is the only registered microbial product for Japanese beetle larval control.

Larval infection is initiated when bacterial spores are ingested, germinate in the gut, infect the gut cells, and enter into insect's blood where they multiply and sporulate. Larvae normally die very slowly, but the exact cause of death is not fully understood. Bacterial spores and parasporal bodies build up in the blood, causing larvae to take on the characteristic milky appearance that gives the disease its name (Fig. 1). The signs produced by milky disease bacteria look macroscopically similar in different scarab species. Although macroscopically similar, microscopically the bacterial spores may differ. For example, the sporangium of the bacteria can differ among scarab species due to the presence or absence of the parasporal body and the position of the spore (Klein \& Jackson 1992). Typical B. popilliae sporangia from Japanese beetle larvae have a "foot print" shape with a large spore and smaller parasporal body (Fig. 2A). Spores from masked chafers, Cyclocephala species, are accompanied by large and multiple parasporal bodies (Fig. 2B). Moreover, infectivity of $B$. popilliae varies among scarab species, being most infective for the species from which it was isolated. For instance, spores from Japanese beetle larvae infected $76 \%$ of Japanese beetles, but only $6 \%$ of northem masked chafers, C. borealis (Klein, unpublished data). Conversely, spores from $C$. borealis infected $47 \%$ of northern masked chafers, but only $3 \%$ of Japanese beetles. However, there is greater infectivity among species of grubs in the same gemus. Spores from $C$. hirta had similar infectivity (45\%) for that species and for $C$. borealis (Kaya \& Klein, unpublished data).

The size of the parasporal body is not an absolute character since Kaya et al. (1992) isolated $B$. popilliae with small, single or large, multiple parasporal bodies in C. hirta in California. Zhang et al. (1988) suggested that the parasporal body is not a stable character and should not be used for species separation. Klein and Jackson (1992) listed milky disease bacteria from over 30 scarab species, but numerous other milky disease-scarab associations probably exist.

Since milky disease bacteria reproduce in the host and reinoculate the soil, they have been introduced into the environment for permanent es-

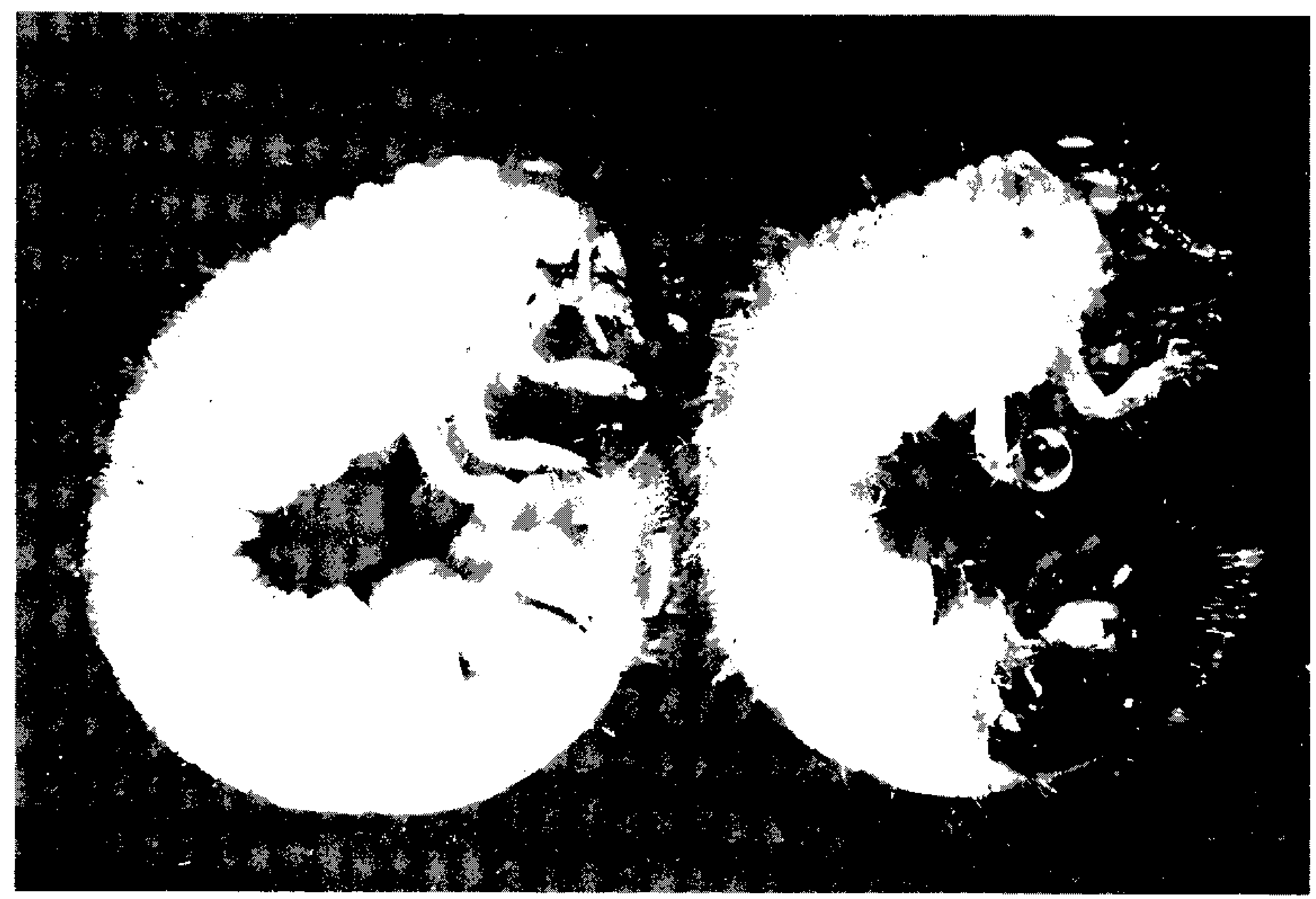

Fig. 1 : milky disease infected (right) and healthy (left) Popillia japonica larvae. 


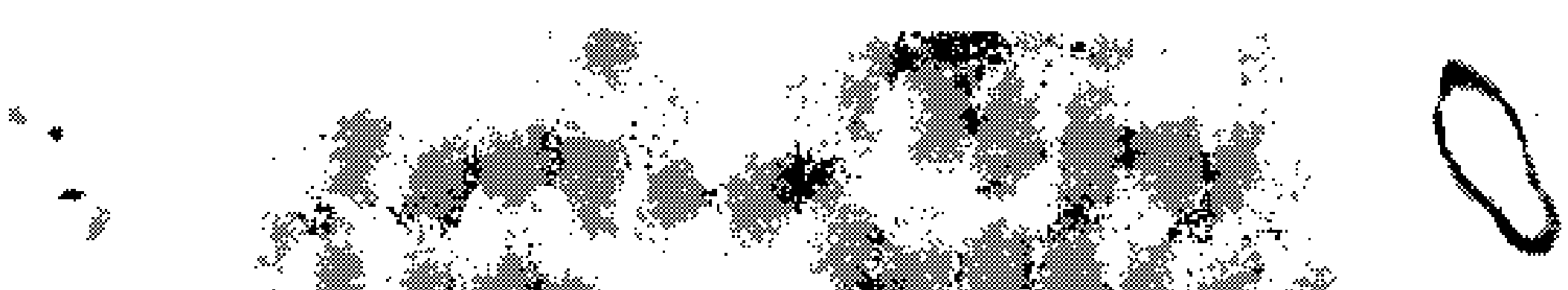

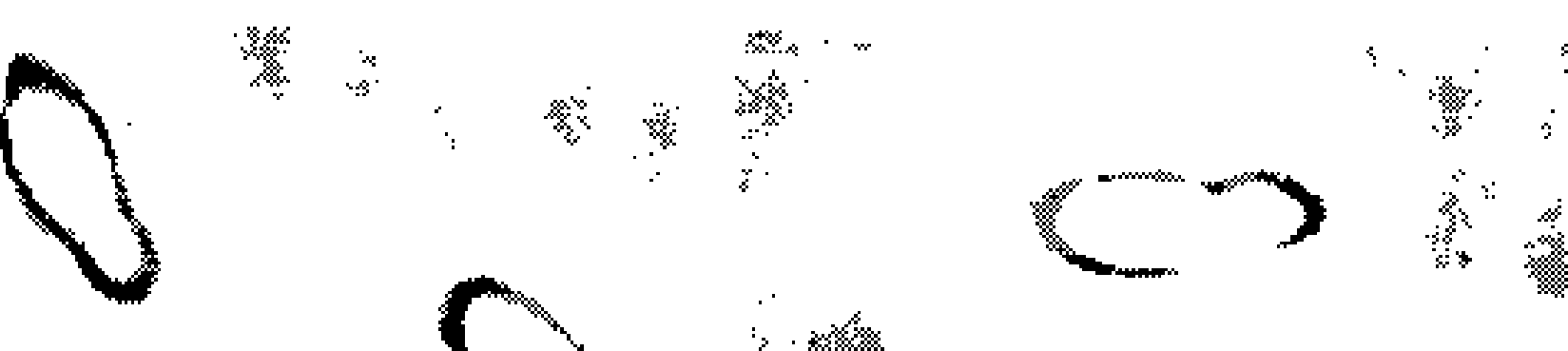

¿

$+$

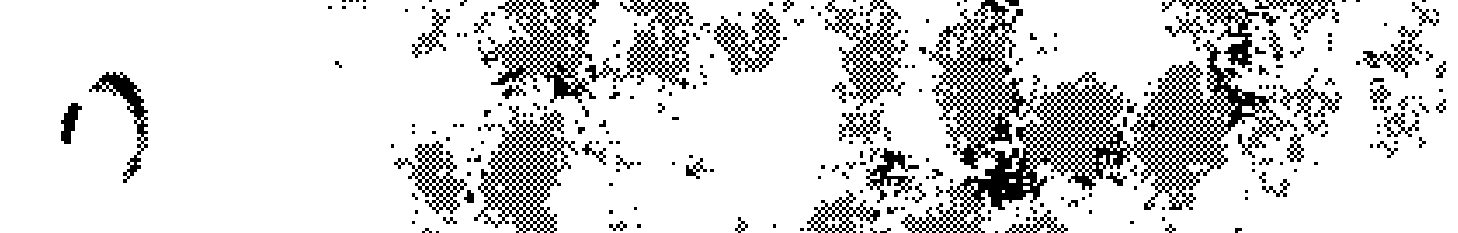

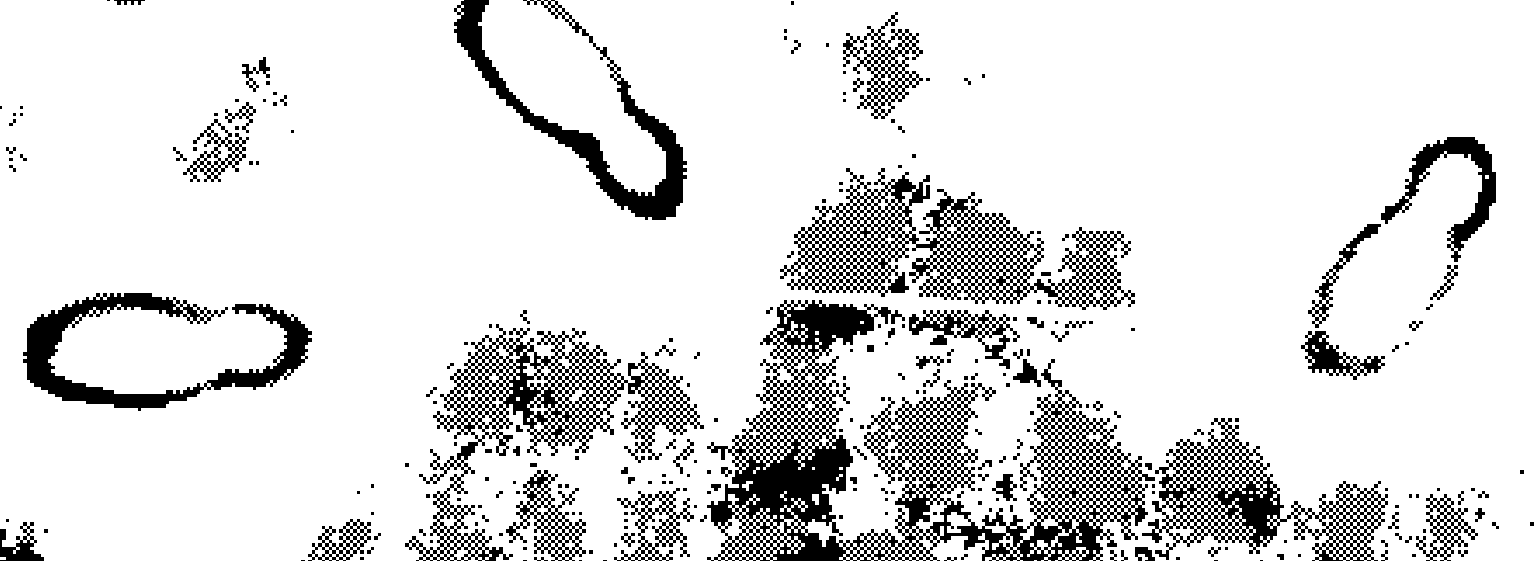

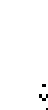

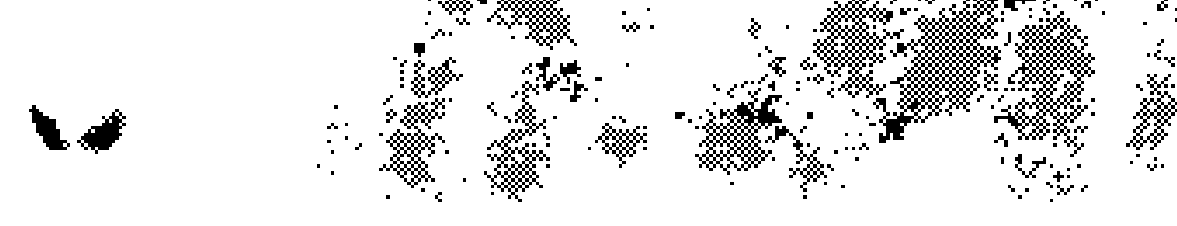

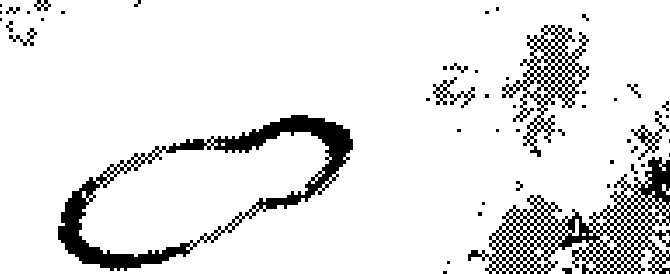

mond

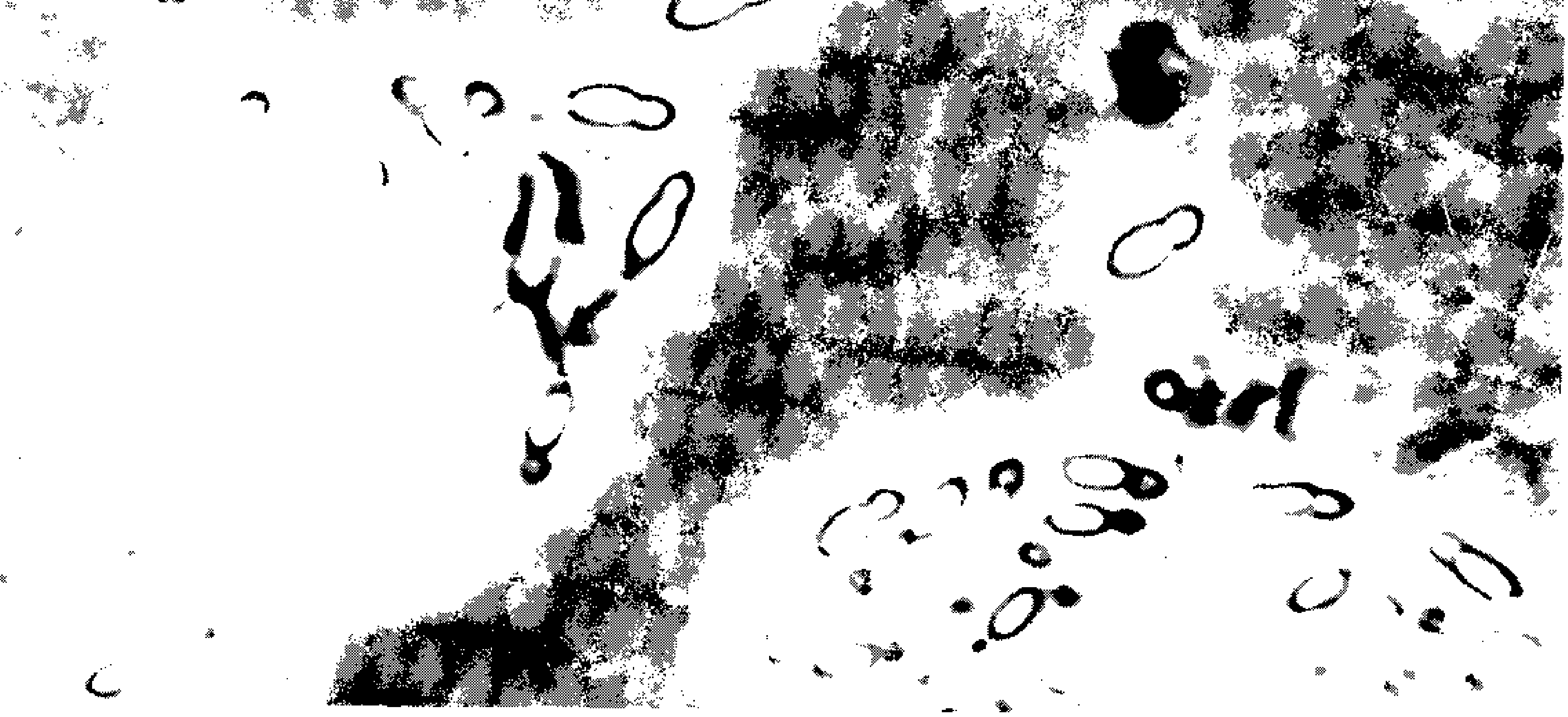

Fig. 2A: Bacillus popilliae spores from Popillia japonica.

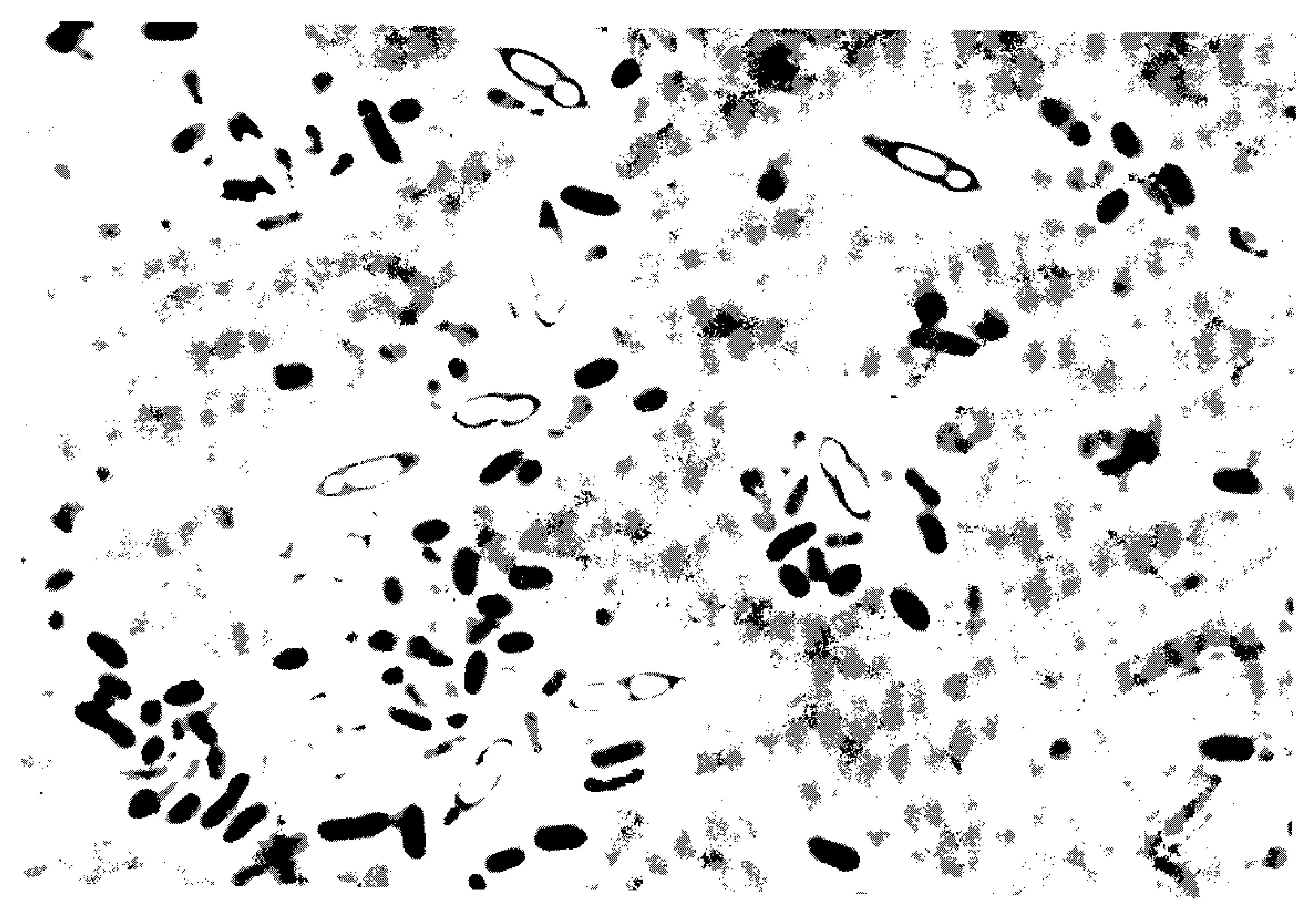

Fig. 2B: Bacillus popilliae spores from Cyclocephala borealis. Note large and multiple parasporal bodies. 
tablishment (an inoculative, augmentative release program). Early work by Dutky (1937) found that $10 \%$ infection could occur in the field two weeks after treatment, and increase to $45 \%$ one year later. Klein (1992) reviewed field tests with milky disease bacteria and noted that results were mixed at best. Recent tests in widely scattered locations have not produced levels of infection equal to historical standards (Cranshaw \& Klein 1994, Shetlar 1994). Studies on Terceira Island, Azores, Portugal, have failed to demonstrate any infectivity in field populations of Japanese beetles two years following applications of $B . p o p$ illiae (Mendes et al. 1994). Although milky disease bacteria have been successful in suppressing Japanese beetle populations, they should not be expected to be a direct replacement for conventional insecticides. Beard (1964) concluded "from a biological standpoint, or a community view, the disease is outstandingly successful by preventing the development of tremendous numbers of beetles, thus reducing the over-all population". On the other hand, "from the standpoint of the individual gardener or greenskeeper who wants to protect his own turf or garden, the infection is not so successful". Thus, in many situations, other control tactics may be needed to suppress white grub populations.

The inability to produce highly infective $B$. popilliae spores on artificial media has severely restricted the use of milky disease spore powder. Until now, milky disease products have been made by finding naturally infected larvae, or by collecting white grubs, infecting them, and extracting the spores. Unfortunately, the patented in vitro method of spore production (Ellis et al. 1989) raised false hopes because the bacteria reported to be $B$. popilliae produced on artificial media were identified as $B$. polymyxa and $B$. amylolyticus (Stahly \& Klein 1992). The in vitro produced spores were formulated as the product Grub Attack ${ }^{\mathrm{TM}}$ (Ringer Corp., Minneapolis, $\mathrm{MN}$ ). Bacteria isolated from the Grub Attack and from cultures deposited in the American Type Culture Collection (ATCC) when the patent was filed were examined and their characteristics were compared to known bacteria. Over 40 physiological characteristics of $B$. polymyxa matched $100 \%$ with those of the Grub Attack and ATCC isolates, whereas those of B. popilliae matched only $25 \%$. Other isolates from Grub Attack and a second ATCC deposit matched B. amylolyticus $100 \%$ and $B$. popilliae $54 \%$. In addition, fatty acid profiles of the isolates from commercial material and the ATCC depositions matched $B$. polymyxa and B. amylolyticus rather than B. popilliae. The bacterial species in samples of the commercial products (Table I) and a lack of infectivity from anything other than $B$. popilliae (Stahly \& Klein 1992) resulted in the withdrawal

of all commercially in vitro produced milky disease spore powder in 1991. The development of an in vitro production method of $B$. popilliae spores, as well as more information on factors influencing disease development in its host, are essential before this bacterium can attain its fullest potential. Barring new breakthroughs, milky disease bacteria will be in short supply and only cause general population suppression and not specific turf protection.

\section{TABLE I}

Bacillus species in 1985-1990 Grub Attack samples

\section{Bacteria}

B. polymyxa

B. popilliae

B. thuringiensis

B. anylolyticus

\section{BACILLUS THURINGIENSIS}

Bt is a naturally occurring soil bacterium that has the ability to produce protein crystals that are toxic to many insects. Its role in turf - omamental pest control has recently been reviewed by Cranshaw and Klein (1994). This bacterium has typically been used as a microbial insecticide. It is a stomach poison and must be ingested to be effective. Although many strains with activity against caterpillar, fly, and beetle larvae have been commercialized; none are currently available for white grub suppression. There has been a concem that the turf-soil ecosystem may not be a very suitable environment for $\mathrm{Bt}$ persistence because soil microorganisms quickly degrade the toxic protein crystal (Klein \& Jackson 1992).

Klein and Jackson (1992) reported that scarab active strains had been isolated in New Zealand, and that the typically lepidopteran $\mathrm{Bt}$ subspecies galleriae and kurstaki had scarab activity against the Japanese beetle in the laboratory and against another white grub species in Chinese peanut fields. The tenebrionis subspecies of $\mathrm{Bt}$ was developed for controlling chrysomelid larvae, in particular the Colorado potato and elm leaf beetles, but some isolates of this subspecies were also active against Japanese beetle and masked chafer, Cyclocephala spp., larvae.

Another Bt with high scarabaeid activity is the subspecies japonensis (Buibui strain) which was isolated from mosquito larvae in Japan (Ohba et al. 1992, Suzuki et al. 1992). This bacterium is toxic to larvae of the Japanese beetle, the cupreous chafer, Anomala cuprea, and the soybean chafer, $A$. rufocuprea, in laboratory tests. More recently, field activity has been reported against the cupreous chafer in Japan (Suzuki et 
al. 1994) and against the Japanese beetle, southern masked chafer, Cyclocephala lurida, and the oriental beetle, Exomala orientalis, in the United States (Shutter et al. 1994).

Additional research is needed to establish the efficacy of these Bt strains, develop delivery systems that maximize the placement of the bacteria near their hosts and develop formulations that minimize the degradation of the toxins in the soil. Possibly the protective coatings such as the $\mathrm{M}$ Cap system developed by Mycogen (San Diego, CA) may enable the toxins to remain active in the soil for longer periods of time. An effort is also under way to use genetic engineering to move the toxic protein crystal from the bacterium into desirable grass plants, thereby affording them protection. However, the possibility of grubs becoming resistant to these toxins needs to be considered, and proper management techniques should be developed before implementing this strategy.

\section{AMBER DISEASE}

Serratia species have often been associated with insect diseases (Klein \& Jackson 1992), but commercial utilization of this genus has been achieved only recently. A commercial product containing $S$. entomophila, is being applied against the grass grub, Costelytra zealandica, in New Zealand pastures (Stucki et al. 1984, Grimont et al. 1988, Jackson et al. 1992, Klein \& Jackson 1992). It is produced by fementation and applied using subsurface application equipment.

Although the S. entomophila from New Zealand is only effective against the grass grub, other scarab larvae have been observed with similar signs and symptoms of this disease (Klein \& Jackson 1992). The bacterium tums the grubs a honey or amber color giving the disease its name. Pathogenic strains of S. entomophila colonize the larval gut, adhere to the crop, and induce starvation which depletes the fat bodies. This series of events ultimately cause the appearance of the amber color (Jackson et al. 1993).

We have isolated Enterobacteriaceae over the past four years primarily from Japanese beetle and masked chafer larvae with amber colotation. We used the Serratia selective medium, caprylate thallous agar, first described by Starr et al. (1976) and previously utilized in New Zealand to isolate S. entomophila (Jackson et al. 1993). Once isolated, the bacteria were further characterized with a series of three media; Dnase (DNA), adonitol (AD), and itaconate (ITAC) agar (O'Callaghan \& Jackson 1993). Serratia species display pink halos after $24 \mathrm{hr}$ of incubation on DNA agar. Yellow colonies are produced by $S$. entomophila, and blue/green colonies by $S$. proteamaculans on AD agar. Growth on ITAC agar is an additional property of S. entomophila. We obtained tenta- tive identification of our bacteria by using the Enterotube ${ }^{\mathrm{R}}$ II system (Becton Dickinson, Cockeysville, MD). The Enterotube system is designed for human not insect pathogens and does not include the amber disease bacteria. However, it does allow preliminary generic designations for the bacteria and indicate the prevalence of Serratia.

We obtained 147 bacterial isolates, characterized their reactions to the three selective media, and recorded the results of the Enterotube II reactions (Table II). The vast majority were positive on DNA agar suggesting that a higher number of Serratia species may be included than indicated by the Enterotubes. More isolates were yellow on the AD agar and positive for growth on ITAC, both characteristics of $S$. entomophila. Nearly half of the isolates came from Japanese beetle larvae, and half of the remaining bacteria were recently isolated from soil and scarab larvae in Japan and China (Table III). Over half of the bacteria were identified as Serratia species on the basis of their Enterotube results, with most of the rest in the genus Enterobacter (Table III). Most of the Serratia isolates came from Ohio Japanese beetles and C. hirta from Califomia (Table IV). Efforts to identify these bacteria are continuing using the MicroStation ${ }^{\text {TM }}$ System (Biolog, Inc., Hayward, CA) which is much more comprehensive and does include $S$. entomophila. We also are establishing the infectivity of Serratia isolates against Japanese beetle and masked chafer larvae, and are continuing to search for more isolates from field-infected scarabs.

Considerable work remains before commercial products would be created from these bacteria. Once the most active Serratia strains have been selected, methods for their production and application as well as registration requirements must be worked out. Amber disease may be more effective against scarabs such as masked chafers which have a tendency to reinfest the same area for many years, rather than the Japanese beetle which tends to shift from one place to another in turf sites.

In conclusion, $B$. popilliae is severely hampered by an inability to grow and sponulate on artificial media. A paucity of material and the lack of rapid reliable action jeopardize the future of this historically important bacterium. $\mathrm{Bt}$ on the other hand is a relatively new candidate for controlling white grubs, and shows promise as a replacement for conventional chemical insecticides. Although $S$. entomophila, the causal agent of amber disease in grass grub, $C$. zealandica, is a commercial success in New Zealand, establishing a role for similar bacteria in other countries requires considerable effort. 
TABLE II

Bacterial isolates from scarab larvae and soil 1990 - 1994

\begin{tabular}{|c|c|c|c|c|c|}
\hline Host & Location/Year & Enterotube II Results & $\mathrm{DNA}^{a}$ & $\mathrm{AD}^{b}$ & ITAC $^{c}$ \\
\hline Anomala sp. & CHIINA/94 & Serratia marcescens; $S$. liquefaciens & + & $\mathrm{y}$ & + \\
\hline Anomala sp. & CHINA/94 & S. marcescens; S. liquefaciens & + & $y$ & + \\
\hline Anomala sp. & CHINA/94 & S. liquefaciens & + & $\mathrm{y}$ & + \\
\hline Anomala sp. & CHINA/94 & Enterobacter & + & $\mathrm{y}$ & + \\
\hline Anomala sp. & CHIINA/94 & Yersina; Shigella & + & $\mathrm{y}$ & + \\
\hline Anomala sp. & CHINA/94 & Enterobacter; Providencia & + & $\mathrm{y}$ & + \\
\hline Anomala sp. & CHINN/94 & Enterobacter & + & $\mathrm{b} / \mathrm{g}$ & + \\
\hline Anomala sp. & JAPAN/92 & S. liquefaciens & + & $y^{\prime}$ & - \\
\hline Cotinis nitida & N. Car $/ 94$ & S. liquefaciens; Klebsiella & + & $y$ & + \\
\hline C. nitida & N. Car/94 & S. liquefaciens & + & $\mathrm{y}$ & - \\
\hline Cyclocephala hirta & Calif $/ 90$ & S. marcescens & + & $y$ & - \\
\hline C. hirta & Calif/91 & Shigella; Enterobacter & + & $\mathrm{y}$ & - \\
\hline C. hirta & Calif/91 & Salmonella & + & $\mathrm{b} / \mathrm{g}$ & + \\
\hline C. hirta & Calif/91 & Salmonella; S. liquefaciens & + & $\mathrm{b} / \mathrm{g}$ & - \\
\hline C. hirta & Calif/91 & Enterobacter & - & $\mathrm{b} / \mathrm{g}$ & + \\
\hline C. hirta & Calif/91 & Enterobacter & - & $\mathrm{b} / \mathrm{g}$ & - \\
\hline C. hirta & Calif/91 & Acinetobacter & - & $y^{0}$ & $+/$ \\
\hline C. hirta & Calif/91 & S. marcescens & + & $\mathrm{y}$ & $+1-$ \\
\hline C. hirta & Calif/91 & Salmonella & + & $\mathrm{b} / \mathrm{g}$ & + \\
\hline C. hirta & Calif/91 & S. marcescens & + & $\mathrm{y}$ & + \\
\hline C. hirta & Calif/91 & S. Liquefaciens; Salmonella & + & $\mathrm{b} / \mathrm{g}$ & + \\
\hline C. hirna & Calif/92 & S. marcescens; S. liquefaciens & + & $\mathrm{y}$ & - \\
\hline C. hirta & Calif/92 & S. liquefaciens; Salmonella & + & $\mathrm{y}$ & - \\
\hline C. hirta & Calif/92 & S. marcescens; S. liquefaciens & + & $\mathrm{y}$ & - \\
\hline C. hirla & Calif/92 & Enterobacter; S. liquefaciens & + & $y$ & - \\
\hline C. hirta & Calif/92 & S. liquefaciens & + & $\mathrm{y}$ & + \\
\hline C. hirta & Calif/92 & Klebsiella & + & $\mathrm{b} / \mathrm{g}$ & + \\
\hline C. hirta & Calif/92 & Klebsiella; S. rubidea & + & $\mathrm{b} / \mathrm{g}$ & - \\
\hline C. hirta & Calif/92 & Enterobacter & + & $\mathrm{b} / \mathrm{g}$ & + \\
\hline C. hirta & Calif/92 & Enterobacter; S. liquefaciens & + & $\mathrm{y}$ & - \\
\hline C. hirta & Calif/92 & Klebsiella & + & $y$ & + \\
\hline C. borealis & Ohio/91 & $\begin{array}{l}\text { Salmonella; Yersinia; Shigella; } \\
\text { S. Liquefaciens }\end{array}$ & - & $\mathrm{b} / \mathrm{g}$ & - \\
\hline C. pasedenae & Calif/93 & Enterobacter & - & $y$ & + \\
\hline C. pasedenae & Calif/93 & Enterobacter & + & $\mathrm{y}$ & + \\
\hline C. pasadenae. & Calif/93 & S. liquefaciens & + & $\mathrm{b} / \mathrm{g}$ & $-1+$ \\
\hline Cyclocephala sp. & Ind $/ 92$ & Enterobacter & + & $\mathrm{y}$ & + \\
\hline Cyclocephalasp. & Ind $/ 92$ & Enterobacter & + & $\mathrm{y}$ & + \\
\hline Exomala orientalis & JAPAN/94 & S. liquefaciens; Salmonella; Arizona & + & $\mathrm{b} / \mathrm{g}$ & + \\
\hline E. orientalis & JAPAN/94 & S. liquefaciens; Salmonella & + & $y$ & + \\
\hline E. orientalis & JAPAN/94 & S. liquefaciens; Salmonella & + & $\mathrm{y}$ & + \\
\hline E. orientalis & JAPAN/94 & S. liquefaciens; Salmonella; Arizona & + & $y$ & + \\
\hline Holotrichia sp. & CHINA/94 & S. liquefaciens; Salmonella; Arizona & + & $\mathrm{y}$ & + \\
\hline Holotrichia sp. & CHINA/94 & S. liquefaciens; Salmonella; Arizona & + & $y$ & + \\
\hline Hoplia sp. & JAPAN/94 & S. marcescens; Hafnia & + & $\mathrm{y}$ & + \\
\hline Popillia japonica & Ohio/90 & Acinetobacter & - & $y$ & + \\
\hline P. japonica & Ohio/ 90 & Yersinia; Shigella & - & $\mathrm{y}$ & - \\
\hline P. japonica & Ohio/ $/ 20$ & Shigella; Enterobacter & - & $\mathrm{y}$ & + \\
\hline P. japonica & Ohiso/91 & Klebsiella & + & $y$ & + \\
\hline P. japonica & Ohio/9l & S. liquefaciens & + & $\mathrm{y}$ & + \\
\hline P. japonica & Ohio/91 & S. liquefaciens; Salmonella & + & $\mathrm{b} / \mathrm{g}$ & + \\
\hline P. japonica & Ohio/9l & S. liquefaciens; Salmonella & + & $\mathrm{b} / \mathrm{g}$ & - \\
\hline P. japonica & Ohio/91 & Klebsiella & + & $y$ & + \\
\hline P. japonica & Ohio/91 & S. liquefaciens & + & $\mathrm{y}$ & + \\
\hline P.japonica & W. Vir/91 & $\begin{array}{l}\text { Salmonella; Yersinia; Shigella; } \\
\text { S. liquefaciens }\end{array}$ & + & h/o & + \\
\hline
\end{tabular}




\begin{tabular}{|c|c|c|}
\hline P. japonica & W. Vir/91 & Klebsiella \\
\hline P. japonica & W. Vir/91 & Shigella; Enterobacter \\
\hline P. japonica & W. Vir/91 & Enterobacter; $S$. liquefaciens \\
\hline$P$. japonica & W. Vir/91 & S. liquefaciens \\
\hline$P$. japonica & W. Vir/91 & Klebsiella; Enterobacter; S. liquefaciens \\
\hline P. japonica & Ohio/91 & Enterobacter \\
\hline P. japonica & Ohio/91 & Shigella; Salmonella; Klebsiella \\
\hline P. japonica & Ohio/91 & Yersinia; Shigella \\
\hline P. japonica & Ohio/91 & Salmonella; S. liquefaciens \\
\hline P. japonica & Ohio/92 & S. liquefaciens; S. marcescens \\
\hline P. japonica & Ind $/ 92$ & S. liquefaciens \\
\hline P. japonica & Ind $/ 92$ & S. liquefaciens; Salmonella; Arizona \\
\hline P. japonica & Ind $/ 92$ & S. liquefaciens \\
\hline P. japonica & $\operatorname{lnd} / 92$ & S. liquefaciens; Salmonella; Arizona \\
\hline$P$. japonica & Ind $/ 92$ & S. liquefaciens; Klebsiella \\
\hline P. japonica & Ind $/ 92$ & S. liquefaciens; Salmonella; Arizona \\
\hline P. japonica & Ind $/ 92$ & S. Liquefaciens; Klebsiella \\
\hline P. japonica & Ohio/93 & S. liquefaciens \\
\hline P. japonica & Ohio/93 & S. marcescens \\
\hline P. japonica & Ohio/93 & Enterobacter \\
\hline P. japonica & Ohio/93 & Enterobacter \\
\hline P. japonica & Ohio/93 & Acinetobacter; Pseudomonas; $2 \mathrm{~K}-\mathrm{I}$ \\
\hline P. japonica & Ohio/93 & Enterobacter; S. liquefaciens \\
\hline P. japonica & Ohio/93 & Enterobacter; Providencia \\
\hline P. japonica & Ohio/93 & S. liquefaciens \\
\hline P. joponica & Ohio/93 & S. liquefaciens; S. marcescens \\
\hline P. japonica & Ohio/93 & S. liquefaciens \\
\hline P. japonica & Ohio/93 & S. liquefaciens \\
\hline P. japonica & Ohio/93 & S. liquefaciens \\
\hline P. japonica & Ohio/93 & S. macescens \\
\hline P. japonica & Ohio/93 & Yersinia; Enterobacter \\
\hline P. japonica & Ohio/93 & S. liquefaciens \\
\hline P. japonica & Ohio/93 & S. liquefaciens \\
\hline P. japonica & Ohio/93 & S. marcescens; S. liquefaciens \\
\hline P. japonica & Ohio/93 & S. marcescens; Hafnia \\
\hline P. japonica & Ohio/93 & Enterobacter \\
\hline P. japonica & Ohio/93 & S. marcescens \\
\hline P. japonica & Ohio/93 & Enterobacter; S. liquefaciens; Yersinia \\
\hline P. japonica & Ohiso/93 & Enterobacter \\
\hline P. japonica & Ohio/93 & Enterobacter \\
\hline P. japonica & Ohio/93 & Enterobacter; S. liquefaciens \\
\hline P. japonica & Ohio/93 & Enterobacter; S. liquefaciens \\
\hline P. japonica & Ohio/93 & Enterobacter \\
\hline P. japonica & Ohio/93 & Enterobacter; S. rubidea \\
\hline P.japonica & Ohio/93 & Enterobacter; Providencia \\
\hline P. japonica & Ohio/93 & Enterobacter \\
\hline P. japonica & Ohio/93 & Enterbacter; S. Liquefaciens \\
\hline P. japonica & Ohio/93 & Enterobacter; Providencia \\
\hline P. japonica & Ohio/93 & S. liquefaciens; Salmonella; Arizona \\
\hline P. japonica & Ohio/93 & S. liquefaciens; Salmonella; Arizona \\
\hline P. japonica & Ohio/93 & S. liquefaciens; Salmonella; Arizona \\
\hline P. japonica & Ohio/93 & S. liquefaciens \\
\hline P. japonica & Ohio/93 & S. liquefaciens \\
\hline P. japonica & Ohio/93 & S. liquefaciens; Salmonella; Arizona \\
\hline$P$. japonica & Ohio/93 & S. liquefaciens \\
\hline P. japonica & Ohio/93 & S. liquefaciens \\
\hline P. japonica & Ohio/93 & S. liquefaciens \\
\hline P. japonica & Ohilo/93 & Enterobacter; S. liquefaciens \\
\hline P. japonica & Ohio/93 & S. liquefaciens \\
\hline P. japonica & Ohio/93 & Enterobacter; S. liquefaciens \\
\hline P. japonica & JAPAN/94 & S. liquefaciens; Salmonella; Arizona \\
\hline$P . j a p o n i c a$ & JAPAN/94 & Enterobacter \\
\hline P. japonica & JAPAN/94 & Hafnia; S. liquefaciens; Enterobacter \\
\hline Popilliasp. & CHINA/94 & S. marcescens; S. liquefaciens \\
\hline soil & CHINA/92 & S. marcescens \\
\hline
\end{tabular}

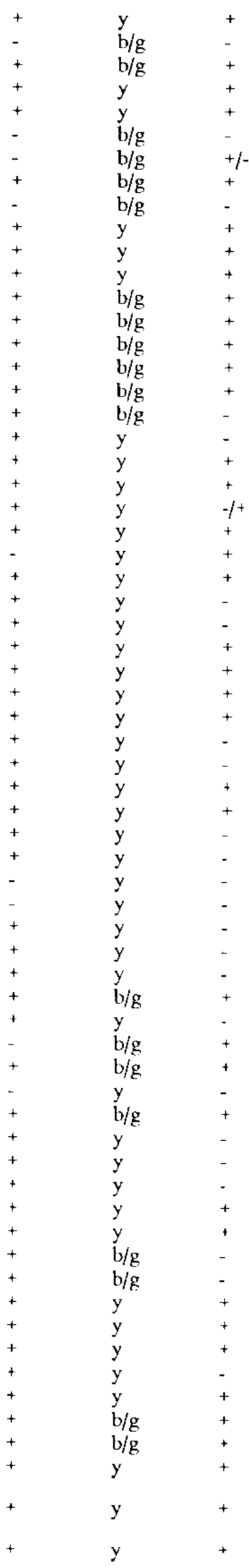




\begin{tabular}{|c|c|c|c|c|c|}
\hline soil & CHINA/92 & Klebsiella & + & $\mathrm{y}$ & + \\
\hline soil & CHINA/92 & Enterobacter; Providencia & + & $\mathbf{y}$ & + \\
\hline soil & JAPAN/94 & S. liquefaciens; Salmonella; Arizona & + & $\mathrm{y}$ & + \\
\hline soil & JAPAN/94 & Enterobacter; S. liquefaciens & - & $y$ & + \\
\hline soil & JAPAN/94 & Pseudomonas; Acinetobacter & + & $y$ & + \\
\hline soil & JAPAN/94 & S. marcescens; Hafnia & + & $y$ & + \\
\hline soil & JAPAN/94 & S. liquefaciens; Salmonella; Arizona & + & $\mathrm{y}$ & + \\
\hline soil & JAPAN/94 & S. marcescens; S. liquefaciens & + & $y$ & + \\
\hline soil & JAPAN/94 & Hafnia; S. liquefaciens; Enterobacter & + & $y$ & + \\
\hline soil & JAPAN/94 & S. liquefaciens; Salmonella; Arizona & + & $\mathrm{b} / \mathrm{g}$ & - \\
\hline soil & JAPAN/94 & Enterobacter; Providencia & + & $\mathrm{b} / \mathrm{g}$ & + \\
\hline soil & $\mathrm{JAPAN} / 94$ & S. marcescens; S. liquefaciens & + & $\mathrm{y}$ & + \\
\hline soil & CHINA/94 & Enterobacter & + & $\mathrm{y}$ & + \\
\hline soil & CHINA/94 & Acinetobacter; Pseudomonas; $2 \mathrm{~K}-1$ & + & $y$ & + \\
\hline soil & CHINA/94 & Acinetobacter; Pseudomonas; $2 \mathrm{~K}-1$ & + & $\mathrm{y}$ & + \\
\hline soil & CHINA/94 & Enterobacter & + & $\mathrm{b} / \mathrm{g}$ & - \\
\hline soil & CHINA/94 & S. marcescens; Hafnia & + & $\mathrm{y}$ & + \\
\hline soil & CHINA/94 & Acinetobacter; Pseudomonas; $2 \mathrm{~K}-1$ & + & $\mathrm{y}$ & + \\
\hline soil & CHINA/94 & S. marcescens; Hafnia & + & $\mathrm{y}$ & - \\
\hline soil & CHINA/94 & Pseudomonas; Acinetobacter & + & $\mathrm{y}$ & + \\
\hline soil & CHINA/94 & Klebsiella; Salmonella & + & $y$ & + \\
\hline soil & CHIINA/94 & Enterobacter & - & $y$ & + \\
\hline soil & CHINA/94 & S. liquefaciens; Salmonella; Arizona & + & $\mathrm{b} / \mathrm{g}$ & + \\
\hline soil & CHINA/94 & Enterobacter & - & $\mathrm{y}$ & + \\
\hline soil & CHINA/94 & S. marcescens; Hafnia & + & $\mathrm{y}$ & + \\
\hline soil & CHINA/94 & Enterobacter; Providencia & + & $\mathrm{y}$ & + \\
\hline
\end{tabular}

a: Serratia species will display pink halos after 24 hr of incubation $(+)$.

$b$ : Serratia entomophila produces yellow colonies (y) and Serratia proteamaculans produces blue/green colonies (b/g) after 24 hr of incubation.

${ }^{c}$ : Serratia entomophila produces growth of new colonies after 4-6 days incubation (+).

\section{TABLE IV}

Serratia isolates recovered from scarab larvae

\section{TABLE III}

Summary of bacterial isolates

Total isolates

Japanese beetle
C. hirta
Other Cyclocephala
Cotinis sp.
Others - Japan and China

Total Serratia isolates (Enterotube II)

Other bacterial isolates (excluding Serratia spp.)

List of genera

$\begin{array}{lr}\text { Acinetobacter } & 6 \\ \text { Enterobacter } & 42 \\ \text { Hafnia } & 2 \\ \text { Klebsiella } & 10 \\ \text { Pseudomonas } & 2 \\ \text { Salmonella } & 6 \\ \text { Shigella } & 4 \\ \text { Yersinia } & 3\end{array}$

and soil samples

$\begin{array}{llc}\text { Host } & \text { Location } & \begin{array}{r}\text { No. Serratia } \\ \text { isolates }\end{array} \\ \text { Anomala sp. } & \text { CHINA } & \cdots \\ & \text { JAPAN } & 3 \\ \text { Cyclocephala hirta } & \text { Califonia } & 1 \\ \text { C.pasedenae } & \text { Califomia } & 8 \\ \text { C. nitida } & \text { North Carolina } & 1 \\ \text { Exomala sp. } & \text { JAPAN } & 2 \\ \text { Holotrichia sp. } & \text { CHINA } & 4 \\ \text { Hoplia } \text { sp. } & \text { JAPAN } & 2 \\ \text { Popillia japonica } & \text { Ohio } & 1 \\ & \text { West Virgin:d } & 27 \\ & \text { Indiana } & 1 \\ & \text { JAPAN } & 7 \\ \text { Popilla sp. } & \text { CHINA } & 1 \\ \text { Soil } & \text { CHINA } & 1 \\ & \text { JAPAN } & 5 \\ & & 6\end{array}$




\section{ACKNOWLEDGMENTS}

To Valeria K Rice for her isolation and characterization of the Enterobacteriaceae bacteria from larvae and soil samples.

\section{REFERENCES}

Beard RL 1964. The present status of milky disease of Japanese beetle in Connecticut, p. 4749. In Proc 2nd colloq invert pathol insects, Paris, 1962.

Cranshaw WS, Klein MG 1994. Microbial control of insect pests and landscape plants, p. 489-505. In A Leslie Handbook of integrated pest management for turf and ornamentals, CRC Press, Boca Raton.

Dutky SR 1937. Investigation of disease of the immature stages of the Japanese beetle. Ph.D Thesis, Rutgers University, New Brunswick, New Jersey, $113 \mathrm{pp}$.

Ellis BJ, Obenchain F, Mehta $\mathrm{R} 1989$. In vitro method for producing infective bacterial spores and sporecontaining insecticidal compositions. United States Patent Number 4,824,671.

Grimont PAD, Jackson TA, Ageron E, Noonan MJ 1988. Serratia entomophila sp. nov. associated with amber disease in the New Zealand grass grub Cos. telytra zealandica. Internat $J$ System Bacteriol 38: $1-6$.

Jackson TA 1992. Scarabs - pests of the past or the future?, p. 1-10. In TA Jackson, TR Glare (eds) Use of pathogens in scarab pest management, Intercept Ltd, Andover.

Jackson TA, Glare TR 1992. Use of pathogens in scarab pest management, Intercept Lid, Andover, $298 \mathrm{pp}$.

Jackson TA, Huger AM, Glare TR 1993. Pathology of amber disease in the New Zealand grass grub Cos. telytra zealandica (Coleoptera: Scarabaeidae). J Invertebr Pathol 61: 1-8.

Jackson TA, Pearson JF, O'Callaghan MO, Mahanty HK, Willocks MJ 1992. Pathogen to product - development of Serratia entomophila (E nterobacteriaceae) as a commercial biological control agent for the New Zealand grass grub (Costelytra zealandica), p. 191-198. In TA Jackson, TR Glare (eds) Use of pathogens in scarab pest management. Intercept Ltd, Andover.

Kaya HK, Kleın MG, Burlando TM 1993. Impact of Bacillus popilliae, Rickettsiella popilliae and entomopathogenic nematodes on a population of the scarabaeid, Cyclocephala hirta. Biocontrol Sci Technol 3: 443-453.

Kaya HK, Klein MG, Burlando TM, Harrison RE, Lacey LA 1992. Prevalence of two Bacillus popilliae Dutky morphotypes and blue disease in Cyclocephala hirta Leconte (Coleoptera: Scarabaeidae) populations in Califomia. Pan-Pac Entomol 68: 38-45.

Klein MG 1988. Pest management of soil-inhabiting insects with microorganisms. Agric Ecosys and Environ 24: 337-349.

Klein MG 1989. Biological suppression of white grubs in turf, p. 297-305. In AR Leslie, RL Metcalf (eds) Integrated pest management for turfgrass and ornamentals, United States Environmental Protection Agency.

Klein MG 1992. Use of Bacillus popilliae in Japanese beetle control, p. 179-189. In TA Jackson, TR Glare (eds) Use of pathogens in scarab pest management, Intercept Ltd, Andover.

Klein MG 1995. Microbial control of turfgrass insects, In RL Brandenburg, MG Villani (eds) ESA handbook of turfgrass insects. (In press).

Klein MG, Jackson TA 1992. Bacterial diseases of scarabs, p. 43-61. In TA Jackson, TR Glare (eds) Use of pathogens in scarab pest management, Intercept Ltd, Andover.

Mendes C, Lacey L, Amaral J, Klein M 1994. Biological control of Popillia japonica on Terceira Island (Azores, Portugal): Potential of Bacillus popilliae. IOBC/WPRS Bulletin 17: 31-34.

O'Callaghan, Jackson TA 1993. Isolation and enumeration of Serratia entomophila - a bacterial pathogen of the New Zeland grass grub, Costelytra zealandica. J Appl Bacteriol 75: 307-314.

Ohba M, Iwahana H, Asano S, Suzuki N, Sato R, Hori H 1992. A unique isolate of Bacillus thuringiensis serovar japonensis with a high larvicidal activity specific for scarabaeid beetles. Letters Appl Microbiol 14: 54-57.

Shetlar DJ 1994. Turfgrass insect and mite management, p. 171-343. In TL Watschke, PH Demoeden, DJ Shetlar (eds) Managing turfgrass pests, Lewis Publishers, Boca Raton.

Shutter RW, Michaels TE, Asano S, Suzuki N, Gelemter WD 1994.Commercial potential of Bacillus thuringiensis var. japonensis for the control of scarab grubs, p. 416. In Proc VIth international colloq invertebr pathol and microb cont, Montpellier.

Stahly DP, Andrews RE, Yousten AA 1992. The genus Bacillus: insect pathogens, p. 1697-1745. In A Balows, HG Truper, M Dworkin, W Harder, KH Schliefer (eds) The procaryotes, Vol.2, SpringerVerlag, Inc. New York.

Stahly DP, Klein MG 1992. Problems with in vitro production of spores of Bacillus popilliae for use in biological control of the Japanese beetle. $J$ Invertebr Pathol 60: 283-291.

Start MP, Grimont PAD, Grimont F, Starr PB 1976. Caprylate-thallous agar medium for selectively isolating Serratia and its utility in the clinical laboratory. J Clinical Microbiol 4: $270-276$.

Stucki G, Jackson TA, Noonan MJ 1984. Isolation and characterisation of Serratia strains pathogenic for larvae of the New Zealand grass grub Costelytra zealandica. NZ J Sci 27: 255-260.

Suzukj N, Hori H, Ogiwara K, Asano S, Sata R, Ohba M, Iwahana H 1992. Insecticidal spectrum of a novel isolate of Bacillus thuringiensis serovar japonensis. Biol Cont 2: 138-142.

Suzuki N, Hori H, Tachibana M, Asano S, Fujiie A 1994. Control of the larvae of cupreous chafer, $A n^{-}$ omala cuprea (Coleoptera:Scarabaeidae), with $B a$ cillus thuringiensis strain Buibui in turfgrass and sweet potato. Biol Cont (In press).

Thurston GS, Kaya HK, Gaugler R 1994. Characterizing the enhanced susceptibility of milky disease-infected scarabaeid grubs to entomopathogenic nematodes. Biol Cont 4: 67-73.

Zhang S, Wan Y, Cui J, Wang B 1988. Study on the morphological change of milky bacteria (Bacillus popilliae) in grubs. Acta Agric Boreali-Sinica 3: 52-57. 